\title{
ULTRAMICRO TECHNIQUES \\ IN ROUTINE CLINICAL LABORATORIES
}

\author{
MR. T. WILLIAMSON, F.I.M.L.T. \\ Leishman Laboratory, Aldershot*
}

SUMMARY: The difficulties in accommodating the occasional ultramicro investigation in smaller clinical laboratories are briefly discussed. Ultramicro modifications of methods for bilirubin, calcium, magnesium, total protein, albumin, phosphorous, glucose and alkaline phosphatase are described which require the minimum of specialised equipment.

\section{Introduction}

For the purposes of this paper the definition of an ultramicro method is fulfilled when it falls into either one or the other of the following categories:

(a) Where the total sample volume required is 0.05 millilitres $(\mathrm{ml})$ or less.

(b) Where the final volume obtained is less than that required to fill a normal spectrophotometer cuvette of a 1 centimetre $(\mathrm{cm})$ light path.

Many technicians will appreciate the problems which can arise when the laboratory is committed to a small but constant demand for pediatric investigations. Many of these must be performed on capillary samples collected by laboratory staff or at best on small volumes of venous blood. Such requests occupy only a small proportion of the daily work load so that the laboratory may not be geared to dealing with very small samples. Some ultramicro systems of analysis can be obtained commercially. ${ }^{1 \cdot 2}$ The experience of the writer has been restricted to the Beckman Spinco system. ${ }^{1}$ In the case of the smaller laboratory the upkeep of this in terms of the maintenance of solutions and operator training time is uneconomical, apart from the possible technical criticism of the methods employed in the system. It is felt that the use of comprehensive kits would best be restricted to a specialised laboratory where they can no doubt be successful when used constantly (Stevens 1965) The remarks of others (Clayton and Jenkins 1966) would seem to support this reservation. Simply scaling down standard techniques is rarely an adequate answer, since stages such as protein precipitation, product precipitation or organic solvent extraction which are conveniently used in standard methods are not so easily used at the ultramicro level without loss of precision. However in modern laboratory practice, two factors have eased the situation.

First, the evolution of more specific and more sensitive procedures has tended towards the requirement of smaller sized samples. A realistic appraisal of current methodology for the estimation of a particular constituent will generally result in the finding of a suitable routine micro method from which an ultramicro version can be developed using essentially identical reagents. Often the only extra equipment necessary is an accurate ultramicro sample pipette.

Second, with the modern spectrophotometer the minimum final volume required in a method can be as low as $3.0 \mathrm{ml}$ to fill a normal $1 \mathrm{~cm}$ cuvette and micro cuvettes are available which require only 0.45 and $0.9 \mathrm{ml}$ respectively to give light paths of 1 and $2 \mathrm{~cm}$.

*Now Senior Technician, Area Central Laboratory, Bath. 


\begin{abstract}
Materials

\section{Instrumental}

The methods described are based on the use of a modern spectrophotometer and for readings in the ultraviolet or near ultraviolet the " minimum slit width technique" is recommended; with micro or semimicro cuvettes it is also necessary to narrow the light beam incident upon the cuvette. On the Unicam SP 500 a condensing lens and a $12 \times 2 \mathrm{~mm}$ slit situated on the filter disc are used for this. Micro cuvettes of $1 \mathrm{~cm}$ and $2 \mathrm{~cm}$ light path are required and for the calcium method semimicro cuvettes ${ }^{3}$ with a funnelled top holding $1.5 \mathrm{ml}$ are recommended for ease of filling and emptying. With the micro cuvettes this is best done with a Pasteur pipette without removal from the micro holder.
\end{abstract}

\title{
Tubes and pipettes
}

The use of ultramicro disposable tubes is not recommended because of the impossibility of examining the clarity of the solution or supernatant contained therein. Where protein precipitation is unavoidable, glass tubes $3.50 \mathrm{~mm}$ by $10 \mathrm{~mm}^{4}$ are useful. Mixing is best done by gentle inversion after capping with " parafilm".

The transfer of supernatants is accomplished with small volumetric or $1.0 \mathrm{ml}$ graduated pipettes. Sanz type pipettes ${ }^{1}$ are used as sample pipettes (Stevens 1965). Sizes of 0.01 and $0.02 \mathrm{ml}$ are required. The precision of Sanz pipettes is good but their accuracy must be checked by careful weighing before routine use is made of them. Graduated 1.0 or $0.5 \mathrm{ml}$ pipettes ${ }^{5}$ can be used for the addition of reagents but better precision is obtained when suitably sized Lang-Levy pipettes are substituted for them.

\section{Methods}

\section{Total Protein. A. Spectrophotometric method (Tombs, Souter and Maclagen 1959)}

Proteins in solution show a specific absorption maximum at $190 \mathrm{~nm}$ due to peptide bonds (Goldfarb, Saidel and Mosovich 1951). The absorption at this wavelength is several times greater than that at the other absorption maximum of $280 \mathrm{~nm}$ which is due to the presence of aromatic amino acids in the peptide chain. Interference from nucleotide absorption is negligible at $210 \mathrm{~nm}$, as is that of free and peptide-linked aromatic amino acids since these show absorption minima between 205 and $210 \mathrm{~nm}$ whilst proteins show a steeply increasing absorption (Fig. 1). Consequently serum proteins are estimated by measuring the extinction of 1 in 2000 saline dilutions at $210 \mathrm{~nm}$ and comparing this with standard albumin solutions similarly treated.

\section{Reagents required}

(a) Saline, $0 \cdot 5 \mathrm{~g} \mathrm{NaC1}$ per $100 \mathrm{ml}$. in water.

This should be fresh, clear of particles and kept exclusively for this technique.

(b) Albumin standards.

For a primary standard, dessicate pure crystalline human albumin (Koch-Light Laboratories Limited, 100 per cent for electrophoresis experiments) over silica gel at $4^{\circ} \mathrm{C}$. Weigh out 0.5 grams, dissolve in saline and make up $500 \mathrm{ml}$.

From this prepare solutions volumetrically of 1.5 and $4.5 \mathrm{mg}$ per $100 \mathrm{ml}$. Measure the optical densities of these and the diluted bovine albumin solutions at $210 \mathrm{~nm}$ in $1 \mathrm{~cm}$ matched Silica cells against saline.

A convenient working standard is 30 per cent w/v bovine albumin (Armour). The exact concentration of this must be checked against a primary standard of purified albumin. Make an initial dilution of the stock 30 per cent to give a saline solution of about $6 \mathrm{~g}$ per $100 \mathrm{ml}$ (Due to the viscosity of the solution, weighing is probably the best approach). Volumetric dilutions of this are then made in saline to 1 in 1500 and 1 in 3000 . (These will correspond to about $8 \mathrm{~g}$ per $100 \mathrm{ml}$ and $4 \mathrm{~g}$ per $100 \mathrm{ml}$ at a 1 in 2000 


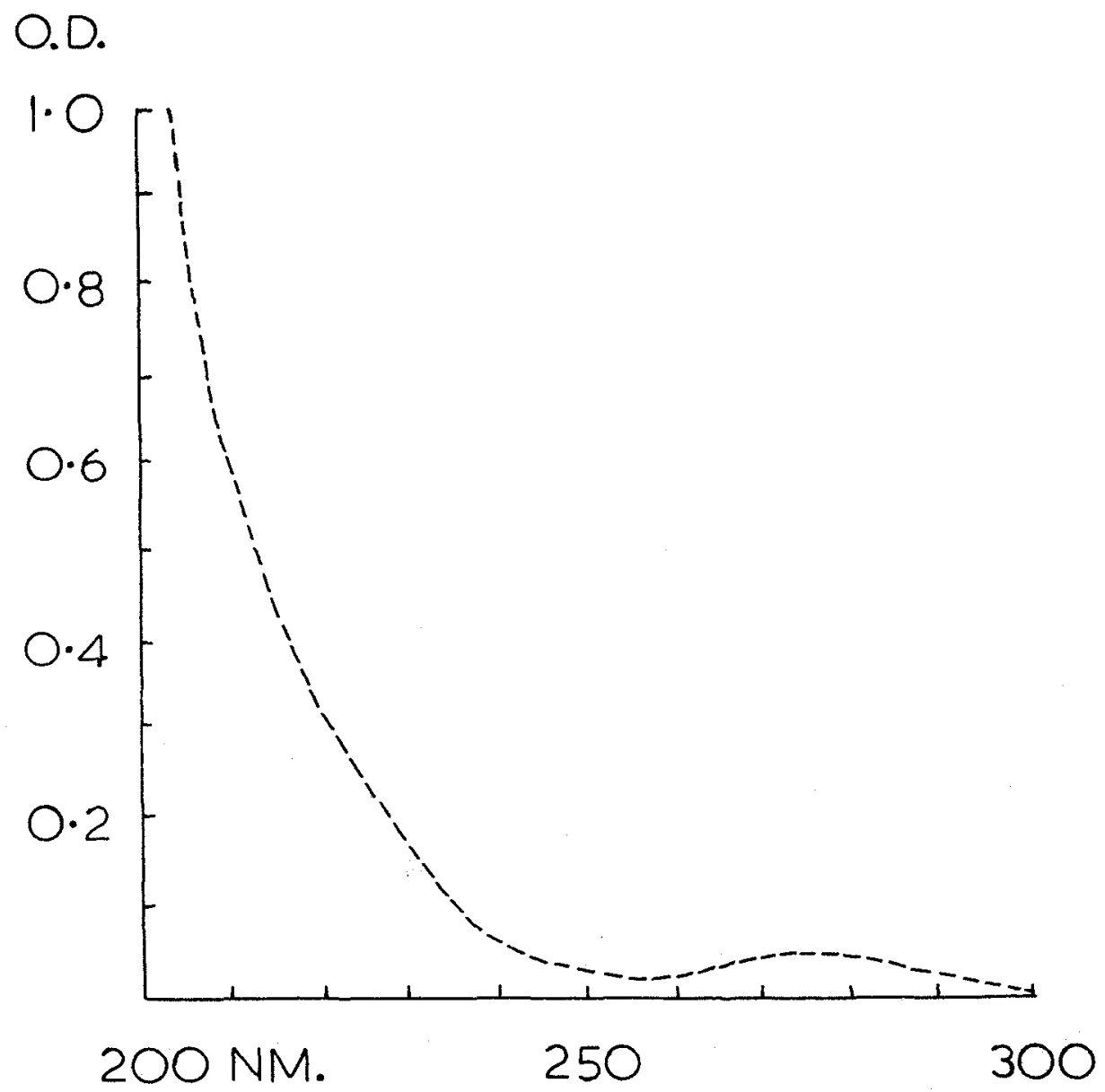

Fig. 1. Absorption spectrum of $3 \mathrm{mg}$ protein per $100 \mathrm{ml}$ in saline from 205 to $300 \mathrm{~nm}$ (Unicam SP 500 in $1 \mathrm{~cm}$ silica cuvettes).

dilution). Calculate the concentration of the stock bovine albumin which is stable for several months at $4^{\circ} \mathrm{C}$ if sterility is maintained. The approximately $6 \mathrm{~g}$ per $100 \mathrm{ml}$ bovine albumin dilution is stable for at least one week at $4^{\circ} \mathrm{C}$ and can be used as the working standard when taken through the test procedure.

\section{Method}

Into a glass tube of suitable capacity pipette $20 \mathrm{ml}$ of saline. Introduce into the surface $0.01 \mathrm{ml}$ of sample. Cap with parafilm, invert to mix and read at $210 \mathrm{~nm}$ against saline in matched $1 \mathrm{~cm}$ silica cuvettes. Notes

1. Beer's law is obeyed to extinctions of greater than 1.5 on a Unicam SP 500 . The use of two standards, high and low, means that it would be possible to detect deviation from linearity due to decreasing emission from an ageing deuterium lamp.

In this paper \pm 2 per cent error was imposed upon the high standard readings. This was not exceeded in 4 months of use at a rate of about 6 hours per week.

2. The readings of diluted samples at $210 \mathrm{~nm}$ begin to increase after 2 hours at room temperature.

3. At $210 \mathrm{~nm}$ the specific absorption of serum proteins at a concentration of $1 \mathrm{~g}$ per $100 \mathrm{ml}$ and in a light path of $1 \mathrm{~cm}$ wass found to average 200 , range 198 to $203\left(210 \mathrm{~nm} \mathrm{E}_{1 \% \mathrm{~cm}}^{1 \%}\right)$. This was compared with protein nitrogen estimations determined by the Kjeldahl method on 4 normal human sera, bovine albumin (Armour) and Versatol freeze-dried human serum. (The factor $6 \cdot 25$ was used to calculate protein from protein nitrogen). 
Total Protein. B. Biuret method (Henry, Sobel and Berkmann 1957)

Where ultraviolet facilities are not available a modified Biuret method may be a suitable alternative.

The Biuret reaction is utilised by diluting serum with copper citrate solution and adding sodium hydroxide separately. The resulting colour is compared with protein standards similarly treated.

Reagents required

(a) Benedicts qualitative glucose reagent, Southern Group Laboratories, Hither Green, Loudon.

(b) Sodium hydroxide solution, $3 \cdot 0 \mathrm{~g}$ per $100 \mathrm{ml}$ in water.

(c) Albumin standards. As for the spectrophotometric method or any albumin solution or whole serum whose protein content has been accurately determined.

Method

Into small glass tubes pipette $0.02 \mathrm{ml}$ of sample, standard albumin and water. Add $0.2 \mathrm{ml}$ of Benedicts reagent and mix. Add 1.0 ml of sodium hydroxide and mix. Stand for 15 minutes at room temperature and if clear read against the blank using $1 \mathrm{~cm}$ micro cuvettes in a spectrophotometer at $540 \mathrm{~nm}$.

Notes

1. Beer's law is obeyed up to readings of 1.0 on a Unicam SP 500.

2. The $540 \mathrm{~nm} \mathrm{E} \mathrm{E}_{1 \mathrm{~cm}}^{1 \%}$ of this method averages $3 \cdot 28$.

3. The occasional development of turbidity on standing or the turbidity due to frank lipaemia of the sample is a disadvantage of any Buiret method. Turbidity due to lipaemia can be avoided in most cases by insisting on fasting specimens. Turbidity which develops on standing has been corrected for by adding a few drops of fresh potassium cyanide to the solution. This dispels the Biuret and copper colour leaving the turbidity which can be read as a blank. Alternatively a copper free blank solution has been used. Both of these methods have been shown to over correct. Ether extraction and centrifuging of the final solution is usually successful.

\section{Correlation between the total protein methods}

Sixty unhaemolysed sera, consisting of pilot samples from 30 volunteer blood donors, 12 ante natal antibody cases, 17 cord samples from normal full term infants and 1 infective hepatitis sample were analysed by the two total protein methods:

(a) The spectro-photometric method (Method A).

(b) The Biuret method (Method B).

The results are shown in Table I.

Table I

Results of two total protein methods in $\mathrm{g}$ per $100 \mathrm{ml}$

\begin{tabular}{|c|c|c|c|c|c|c|c|c|}
\hline \multirow[t]{2}{*}{ Group } & \multirow[t]{2}{*}{ No. } & \multicolumn{2}{|c|}{ Ranges } & \multicolumn{2}{|c|}{ Means } & \multicolumn{2}{|c|}{$\begin{array}{l}\text { Standard } \\
\text { deviation }\end{array}$} & \multirow{2}{*}{ Correlation } \\
\hline & & A & B & A & B & A & B & \\
\hline $\begin{array}{l}\text { Blood donors } \\
\text { Ante natals } \\
\text { Neonates } \\
\text { Hepatitis }\end{array}$ & $\begin{array}{r}30 \\
12 \\
17 \\
1\end{array}$ & $\begin{array}{c}5 \cdot 79-7 \cdot 30 \\
5 \cdot 60-6 \cdot 75 \\
4 \cdot 95-8 \cdot 40 \\
8 \cdot 40\end{array}$ & $\begin{array}{c}6.05-7.45 \\
5 \cdot 70-6.85 \\
5 \cdot 00-8.30 \\
8 \cdot 30\end{array}$ & $\begin{array}{l}6 \cdot 62 \\
6 \cdot 20 \\
5 \cdot 96 \\
-\end{array}$ & $\begin{array}{c}6 \cdot 61 \\
6 \cdot 10 \\
5 \cdot 98 \\
-\end{array}$ & $\begin{array}{l}0.36 \\
0.31 \\
0.76 \\
-\end{array}$ & $\begin{array}{l}0.39 \\
0.36 \\
0.82 \\
-\end{array}$ & $\begin{array}{l}0.985 \\
0.986 \\
0.992\end{array}$ \\
\hline \multicolumn{3}{|c|}{ Overall method means } & & $6 \cdot 34$ & $6 \cdot 32$ & & & \\
\hline
\end{tabular}

Grood agreement is obtained between the two methods for each of the sample groups. The cord blood samples with one exception displayed a much lower range and mean compared with the other two sample groups.

Serum Albumin. A. Spectrophotometric method (Tombs, Souter and MacLagen 1959)

Globulins are precipitated by half saturation with ammonium sulphate. The 
albumin containing supernatant is diluted with water and the absorption at $210 \mathrm{~nm}$ is compared with that of standard albumin solutions. The final dilution of the test sample is 1 in 1000 .

\section{Reagents required}

Ammonium sulphate, half saturated, 2.09 molar. $27.6 \mathrm{~g}$ per $100 \mathrm{ml}$ in water. This can be stored at room temperature.

Method

With a graduated pipette deliver $0.98 \mathrm{ml}$ ammonium sulphate into a small glass centrifuge tube. Add $0.02 \mathrm{ml}$ of test serum, cap with parafilm and invert gently to mix. Stand for 20 minutes at room temperature, then centrifuge at top speed for 15 minutes. Remove $0.5 \mathrm{ml}$ of supernatant and place it in a $10 \mathrm{ml}$ volumetric flask. Make up to the mark with water, invert to mix and read against a similar reagent blank at $210 \mathrm{~nm}$ in a $1 \mathrm{~cm}$ silica cuvette. Compare with albumin standards in saline as before.

\section{Serum Albumin. B. Dye binding method (Harding and Keyser 1968, based on Bartholomew and Delaney 1966)}

Serum is added to brom cresol green buffered at $\mathrm{pH} 3.8$. The increase in readings at $640 \mathrm{~nm}$ is related to a standard curve based on identically treated dilutions of normal serum whose albumin content is known.

Reagents required

(a) Sodium citrate, molar. $29 \cdot 4 \mathrm{~g} \mathrm{Na}_{3} \mathrm{C}_{6} \mathrm{H}_{5} \mathrm{O}_{7} 2 \mathrm{H}_{2} \mathrm{O}$, per $100 \mathrm{ml}$ in water.

(b) Citric acid, molar. $21.0 \mathrm{~g} \mathrm{C}_{6} \mathrm{H}_{8} \mathrm{O}_{7} . \mathrm{H}_{2} \mathrm{O}$, per $100 \mathrm{ml}$ in water.

(c) Brom cresol green, 0.01 molar. Dissolve 0.698 brom cresol green indicator grade (Hopkins and Williams Ltd.) in $9.8 \mathrm{ml}$ of 0.1 normal sodium hydroxide. Make up to $100 \mathrm{ml}$ with water.

(d) Buffered brom cresol green reagent. To about $80 \mathrm{ml}$ of water in a $100 \mathrm{ml}$ volumetric flask add 1.73 and $3.3 \mathrm{ml}$ of sodium citrate and citric acid respectively. Add $0.6 \mathrm{ml}$ of brom cresol green, mix and check the $\mathrm{pH}$. Adjust to 3.8 if necessary, Make up to volume with water. Add $0.1 \mathrm{ml}$ of Brij ${ }^{6}$ ( $25 \mathrm{~g}$ per $100 \mathrm{ml}$ in water).

(e) Buffered blank reagent. Proceed as for reagent (d) but miss out the dye.

The stock dye and buffer solutions are stable for at least 3 months at $4^{\circ} \mathrm{C}$. The working reagents are stable for at least 2 weeks at $4^{\circ} \mathrm{C}$. Allow the working reagents to come to room temperature before use. Method

Into each of two tubes pipette $0.01 \mathrm{ml}$ of test serum followed by $2 \mathrm{ml}$ of buffered dye into one tube for the test and into the other the same volume of buffer blank reagent. Flick to mix, stand for 5 minutes and read against distilled water at $640 \mathrm{~nm}$ in $2 \mathrm{~cm}$ micro cuvettes. Deduct the reading of the serum blank (if any) from that of the test. Compare the corrected reading with a calibration curve (See Note 1).

Notes

1. Preparation of a calibration curve.

Purified crystalline human albumin preparations are not electrophoretically homogenous (Keyser 1965 ) and differ in their dye binding characteristics from the albumin of shed human sera (Nankiville and Watson 1964). Crystalline albumin should not be used for the preparation of calibration curves. The method is standardised using dilutions of pooled normal human sera whose albumin content has been determined by another method. When this is done, results by the brom cresol green method agree with those obtained by other methods, including one specific immuno precipitation technique (Harding and Keyser 1968).

\section{Directions}

Obtain a normal serum pool from at least four individual samples. Concentrate the serum proteins by standing the serum over Lyphogel ${ }^{7}$ crystals until the total protein is about $9 \mathrm{~g}$ per $100 \mathrm{ml}$. Determine the albumin content of the serum by either the spectrophotometric method above or a salt fractionation/ Biuret method. Distribute the serum into $5 \mathrm{ml}$ amounts and freeze at $-10^{\circ} \mathrm{C}$. For the calibration curve, make dilutions of the serum in saline $1 / 5,1 / 4,1 / 3$ etc. and take these through the procedure exactly as a test. Use the reading of the neat dye reagent as a zero point on the graph. A new curve is necessary with a fresh batch of reagents.

2. Beer's law is not obeyed by the dye/albumin complex. For this reason the aim should be to cover from zero to about $6.0 \mathrm{~g}$ per $100 \mathrm{ml}$. albumin on the calibration curve using at least five points.

3. Provided that any turbidity contributed to the final solution by the sample is compensated for in an indicator-free blank reagent, the brom cresol green method has been shown to give reliable results even in the presence of bilirubin and free haemoglobin (Northam and Widdowson 1967).

\section{Inorganic Phosphorous (based on Stevens 1965 and Dryer, Tammes and Routh 1957)}

The phosphorous in a trichloracetic filtrate of serum is coupled with acid molybdate 
to form phosphomolybdate. This is reduced by the addition of copper and ascorbic acid. The resulting colour is read at $330 \mathrm{~nm}$ and compare with that of a standard similarly treated. The absorbance at $330 \mathrm{~nm}$ is four times that at $750 \mathrm{~nm}$ (Fig. 2).

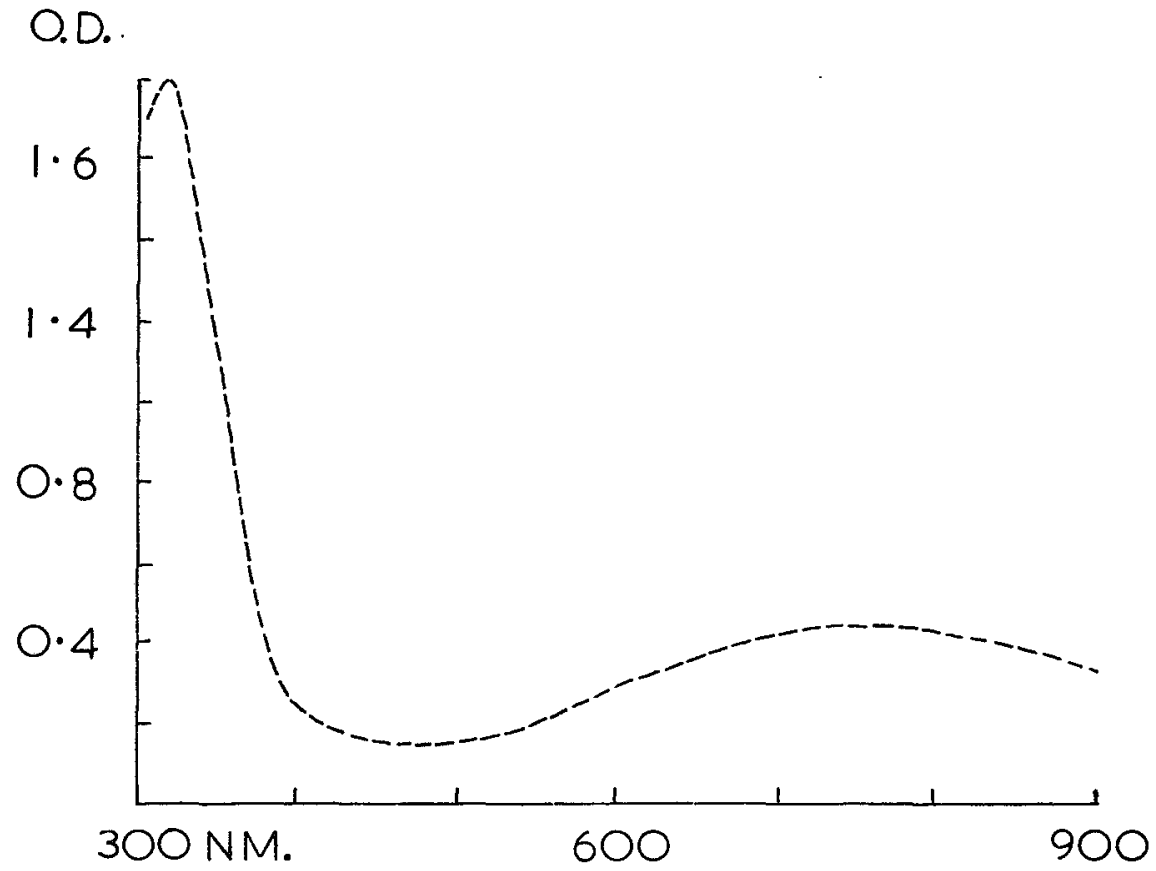

Fig. 2. Absorption spectrum of molybdenum blue between 310 and $900 \mathrm{~nm}$ at a final concentration of $0.006 \mathrm{mg}$ phosphorous in $3.4 \mathrm{ml}$ (Unicam SP 500,1 cm silica cuvette, against reagent blank)

\section{Reagents required}

(a) Trichloroacetic acid, $7 \cdot 5 \mathrm{~g}$ per $100 \mathrm{ml}$ in water.

(b) Molybdic acid. Dissolve 3.75 grams sodium molybdate in water. Add $14 \mathrm{ml}$ of concentrated sulphuric acid $(1.84$ S.G.) and make up to $200 \mathrm{ml}$ with water. Store in polythene bottles. Stable indefinitely.

(c) Stock copper reagent. $200 \mathrm{mg}$ per $\mathrm{CuSO}_{4} .5 \mathrm{H}_{2} \mathrm{O}$ per $100 \mathrm{ml}$ in water.

(d) Reducer. Prepare fresh daily by dissolving $40 \mathrm{mg}$ ascorbic acid in $20 \mathrm{ml}$ of stock copper reagent.

(e) Standard phosphorous, $10 \mathrm{mg}$ per $100 \mathrm{ml}$ in water. Dissolve $0.4375 \mathrm{~g}$ desiccated $\mathrm{KH}_{3} \mathrm{PO}_{4}$ in water and make up to 1 litre. Store in polythene bottles at $4^{\circ} \mathrm{C}$.

\section{Method}

Into 3 centrifuge tubes pipette $1 \mathrm{ml}$ of water. Add $0.05 \mathrm{ml}$ of serum, standard phosphorous solutions and water for the test standard and blank. Mix and add $2 \mathrm{ml}$ of trichloroacetic acid. Cap with parafilm and invert gently to mix. Avoid foaming and stand for 30 minutes. Centrifuge at maximum speed for 10 minutes and look for visible turbidity by the Tyndal effect. Take off $2 \mathrm{ml}$ of supernatant and to it add 0.4 and $1 \mathrm{ml}$ respectively of molybdic acid and reducer. Mix and stand for 20 minutes. Read against the blank in $1 \mathrm{~cm}$ silica cuvettes at $330 \mathrm{~nm}$.

\section{Notes}

1. For situations where ultraviolet facilities are not available an alternative micro method is to substitute $0.2 \mathrm{ml}$ of test standard. The method is then followed exactly but read at $750 \mathrm{~nm}$.

2. Beer's law is obeyed at 330 and $750 \mathrm{~nm}$ to greater than $10 \mathrm{mg}$ per $100 \mathrm{ml}$.

3. Colour development proceeds rapidly to a near maximum at 20 minutes, then increases by very small increments for up to 45 minutes. This occurs at 330 and $750 \mathrm{~nm}$. The method is determined by taking readings between 20 and 30 minutes.

4. Turbidity may be detected by the Tyndal effect in the supernates from some sera. It can sometimes be excluded and always diminished by remixing the precipitate and heating at $90^{\circ} \mathrm{C}$ for 15 minutes. The tube is then cooled and kept at $0-4^{\circ} \mathrm{C}$ for several hours. After a gentle remixing it is centrifuged. The 
absorption spectra of serum trichloroacetic acid supernates have been studied and whilst the absorbance in the presence of a molybdate free reagent is almost nil at $750 \mathrm{~nm}$ for all kinds of samples, the largest ever encountered at $330 \mathrm{~nm}$ was 0.015 . This was with a grossly lipaemic sample. Samples of normal appearance or with slight lipaemia show background absorptions under these conditions of less than 0.01 .

\section{Blood Glucose (adapted from Trinder 1969)}

Blood glucose levels of neonates can be very low, values of $<20 \mathrm{mg}$ per cent occurring frequently. Because of the fragility of the neonate erythrocytes some breakdown of the cells is inevitable, no matter what mode of sample collection is adopted. This can cause serious positive errors when a non specific reduction method of estimation is used (Stevens 1965). In the interests of accuracy a case must be argued for the adoption of a specific glucose method for possibly low pediatric samples. The method of Trinder using glucose oxidase and a non-carcinogenic chromogen uses only two solutions, both of which are stable.

A buffered protein free filtrate of whole blood is incubated with reagent containing glucose oxidase, peroxidase and 4-amino phenazone. The glucose is oxidised to gluconic acid and the peroxide formed oxidises the 4-amino phenazone catalysed by peroxidase. The coloured oxidation product of 4-amino phenazone is compared with that of a standard glucose solution similarly treated.

\section{Reagents required}

(a) Protein precipitant. Dissolve in $800 \mathrm{ml}$ of water, $9 \mathrm{~g} \mathrm{NaCl}, 10 \mathrm{~g} \mathrm{Na} \mathrm{NO}_{4} \cdot 2 \mathrm{H}_{2} \mathrm{O}, 10 \mathrm{~g}$ phenol. Add enough $\mathrm{N} . \mathrm{HCl}$ to give a pH of 3.0 (narrow range indicator papers), usually approx. $125 \mathrm{ml}$. Make up to 1 litre with water. Stable indefinitely.

(b) Stock reagent buffer. Dissolve $10 \mathrm{~g} \mathrm{Na}_{2} \mathrm{HPO}_{4}$ and $1 \mathrm{~g} \mathrm{NaN}_{3}$ in water and make up to 1 litre. Stable indefinitely.

(c) Colour reagent. To $300 \mathrm{ml}$ stock reagent buffer add $200 \mathrm{mg}$ glucose oxidase (Sigma grade II), $5 \mathrm{mg}$ peroxidase (R.Z. 0.6) and $90 \mathrm{mg} 4$-amino phenazone. Stable one month at $4^{\circ} \mathrm{C}$.

(d) Standards. Dilute $4 \mathrm{ml}$ and $8 \mathrm{ml}$ of glucose solution $(100 \mathrm{mg}$ of glucose per $100 \mathrm{ml}$ of saturated benzoic acid solution) to $250 \mathrm{ml}$ with protein precipitant. These correspond to 50 and $100 \mathrm{mg}$ per $100 \mathrm{ml}$ of glucose when treated as supernatant. Stable indefinitely at $4^{\circ} \mathrm{C}$.

Method

Add $0.05 \mathrm{ml}$ fluoride or capillary sample to $1.5 \mathrm{ml}$ protein precipitant. Mix and centrifuge. To $1 \mathrm{ml}$ supernatant add $2 \mathrm{ml}$ colour reagent, mix vigorously and incubate for 20 minutes at $37^{\circ} \mathrm{C}$. Treat $1.0 \mathrm{ml}$ of protein precipitant similarly for a blank and $1.0 \mathrm{ml}$ of the glucose standards. Cool and read all tubes against the blank at $515 \mathrm{~nm}$ in $1 \mathrm{~cm}$. glass cuvettes for normal and raised values or in $2 \mathrm{~cm}$ micro cuvettes for low values.

Notes

1. Beer's law is obeyed up to at least $500 \mathrm{mg}$ per $100 \mathrm{ml}$ and the colour is stable from 20 minutes to more than 1 hour.

\section{Alkaline Phosphatase (Babson, Greeley, Coleman and Phillips 1966)}

Serum is incubated with buffered phenolphthalein monophosphate. Free phenolphthalein is liberated. The reaction is stopped by the addition of an alkaline buffer which also develops the colour of the phenolphthalein. This is read and results are obtained from a calibration curve based on pure phenolphthalein solutions. The method forms the basis of the "Phosphastrate" kit (William R. Warner).

\section{Reagents required}

For the kit, reconstitute reagents exactly as the manufacturers' instructions.

(a) Stock substrate. This is 65 millimolar phenolphthalein in 7.8 molar 2-amino-2-methyl-1-propanol buffered to $\mathrm{pH} 10^{\cdot 15}$ with dicyclohexylamine and hydrochloric acid. The concentrate should be warmed to room temperature before use. Stable indefinitely at $0-5^{\circ} \mathrm{C}$.

(b) Colour developer. This is a $0 \cdot 1$ molar phosphate buffer of $\mathrm{pH} 11 \cdot 2$. Dissolve $9 \cdot 3 \mathrm{~g} \mathrm{Na}_{3} \mathrm{PO}_{4} \cdot 12 \mathrm{H}_{2} \mathrm{O}$ and $20 \cdot 3 \mathrm{~g} \mathrm{Na}_{2} \mathrm{HPO}_{4} .7 \mathrm{H}_{2} \mathrm{O}$ in water and dilute to 1 litre. Stable at $4^{\circ} \mathrm{C}$ indefinitely.

Method

Dilute 1 drop of stock substrate with $1 \mathrm{ml}$ of water. Pipette $0.2 \mathrm{ml}$ into a small tube. Warm to $37^{\circ} \mathrm{C}$ for a few minutes and add $0.02 \mathrm{ml}$ of serum. Incubate for 15 minutes and add $1 \mathrm{ml}$ of colour developer. 
Mix and read at $550 \mathrm{~nm}$ against a reagent blank in 1 or $2 \mathrm{~cm}$ micro cuvettes.

Read off on a calibration curve (see Note 1). Notes

1. In the "Phosphastrate" version of this method standardisation is recommended by the construction of a calibration curve based on the activity of "Versatol " frecze-dried human sera which have "weighed in" enzyme values. It is known that the various isoenzymes of alkaline phosphatase which can occur in human sera do not display identical affinities towards any substrate (Wolf, Dinwoodie and Morgan 1969, Nisselbaum, Schlamouitz and Bodansky 1961, Williamson 1972).

Standardisation of this procedure against the activity of a particular weighed in enzyme component or components is dismissed in favour of using a calibration curve based on pure phenolphthalein.

\section{Directions}

Dessicate pure phenolphthalein over silica gel, weigh out $0.4775 \mathrm{~g}$, dissolve in 70 per cent $\mathrm{v} / \mathrm{v}$ methanol and make up to 1 litre with methanol. This is a 1.5 millimolar solution, $1 \mathrm{ml}$ of which corresponds to 1000 I.U./litre when taken through the procedure. The international unit is defined as that amount of enzyme in 1 litre of serum which will catalyze the hydrolysis of 1 micromole of substrate per minute under the described conditions.

The calibration curve is constructed by firstly diluting the stock standard 1 in 4 with aqueous methanol and setting up a series of tubes as Table II.

Table II

Calibration curve--setting up series of tubes

\begin{tabular}{l|c|c|c|c|c|c|c}
\hline \multirow{2}{*}{ Stock } & \multicolumn{7}{c|}{ Tube number } \\
\cline { 2 - 7 } & 1 & 2 & 3 & 4 & 5 & 6 & 7 \\
\hline $\begin{array}{l}\text { ml diluted } \\
\text { phenolphalein }\end{array}$ & NIL & $0 \cdot 1$ & $0 \cdot 2$ & $0 \cdot 4$ & $0 \cdot 6$ & $0 \cdot 8$ & $1 \cdot 0$ \\
\hline $\begin{array}{l}\text { ml aqueous } \\
\text { menthanol }\end{array}$ & $1 \cdot 1$ & $1 \cdot 0$ & $0 \cdot 9$ & $0 \cdot 7$ & $0 \cdot 5$ & $0 \cdot 3$ & $0 \cdot 1$ \\
\hline $\begin{array}{l}\text { Value in } \\
\text { I.U./litre }\end{array}$ & Blank & 25 & 50 & 100 & 150 & 200 & 250 \\
\hline
\end{tabular}

To each add $5 \mathrm{mI}$ of colour developer, 1 drop stock substrate. Mix and read at $550 \mathrm{~nm}$.

2. Beer's law is obeyed to concentrations of phenolphthalein corresponding to 200 I.U./litre on a Unicam SP 500.

Above 100 I.U./litre zero order kinetics with respect to enzyme concentration are not obeyed for most sera with high activities, and it is necessary to stop the reaction earlier. Thus if at 5 or 10 minutes the tubes are inspected and from the colour high results are to be expected, the reaction can be stopped at specific time and results calculated on this basis.

\section{Calcium (based on Radin and Gramza 1964)}

This method depends upon the different spectral characteristics of the metal indicator Eriochrome Blue SE in the free state and combined with calcium. At the alkaline $\mathrm{pH}$ used magnesium does not interfere. The optical density of the buffered dye solution is determined at $610 \mathrm{~nm}$ before and after the addition of serum. The decrease in absorbance is related to that of calcium standards similarly treated. Since Beer's law is not obeyed a calibration curve is necessary.

Reagents required

(a) Eriochrome Blue SE (Hopkins and Williams Ltd.). Dissolve $532.7 \mathrm{mg}$ of dye in 1 litre of water acidified with $0.7 \mathrm{ml}$ of IN HCI. Stable indefinitely at room temperature.

(b) Potassium Hydroxide 5N.

(c) Calcium standards. Weigh out $1.25 \mathrm{~g}$ desiccated $\mathrm{CaCO}_{3}$. Dissolve in water containing $50 \mathrm{ml}$ of IN HCI and make up to 1 litre. This is a stock $500 \mathrm{mg}$ per $100 \mathrm{ml}$ solution. For use, dilute 1, 2, and $3 \mathrm{ml}$ to $10 \mathrm{ml}$ for working standards of 5,10 and $15 \mathrm{mg}$ per $100 \mathrm{ml}$. Store all standards in polythene bottles.

(d) Working dye. Mix 1 volume of dye with 8 volumes of water. Add I volume of 5 NKOII and use within 1 hour.

(e) Reference solution. Mix 1 volume working dye with 1 volume of water. 


\section{Method}

Into $1 \mathrm{~cm}$ semimicro cuvettes pipette $1.5 \mathrm{ml}$ of working dye. Determine the optical density at $610 \mathrm{~nm}$ against fresh reference solution. Add $0.02 \mathrm{ml}$ of test serum, close the cuvette with a finger tip covered in parafilm and invert to mix. Again determine the optical density at $610 \mathrm{~nm}$ and deduct from the first reading . Determine the change in optical density for each of the 3 calcium standards. In between samplings, wash out the cuvette with water, followed by a rinse with working dye; then shake the cuvette as dry as possible. Plot the standard readings on graph paper and read off the test concentration. It is necessary to produce a calibration curve with every batch of dye reagent. Three standard calcium solutions are adequate for usual purposes.

Notes

1. Interference by haemoglobin, bilirubin and lipaemia. Normal fasting sera contribute no significant reading to the solution at $610 \mathrm{~nm}$ and neither do jaundiced nor haemolysed sera. Lipaemia in any degree does, however. The effect of lipaemia can be corrected by putting up an alkaline serum blank. This is $1.5 \mathrm{ml}$ of $0.5 \mathrm{~N} \mathrm{KOH}$ with $0.02 \mathrm{ml}$ of the lipaemic serum added and read at $610 \mathrm{~nm}$ against $0.5 \mathrm{~N} \mathrm{KOH}$. The corrected reading for the test then becomes:

O.D. change for test + O.D. serum blank.

\section{Magnesium (based on Rice and Lapara 1964)}

Magnesium ions cause the dye sodium 1-azo-2-hydroxy-3 (2, 4-dimethylcarboxanilide) naphthalene-1 (2-hydroxy benzene-4-sulphonate) or "Mann" dye to change colour from blue to purple between $\mathrm{pH} 8$ and 11 in dilute alcoholic solution.

The absorption peak of the free dye at $600 \mathrm{~nm}$ decreases with added magnesium ions as shown in Fig. 3. The decrease in optical density at this wavelength is proportional

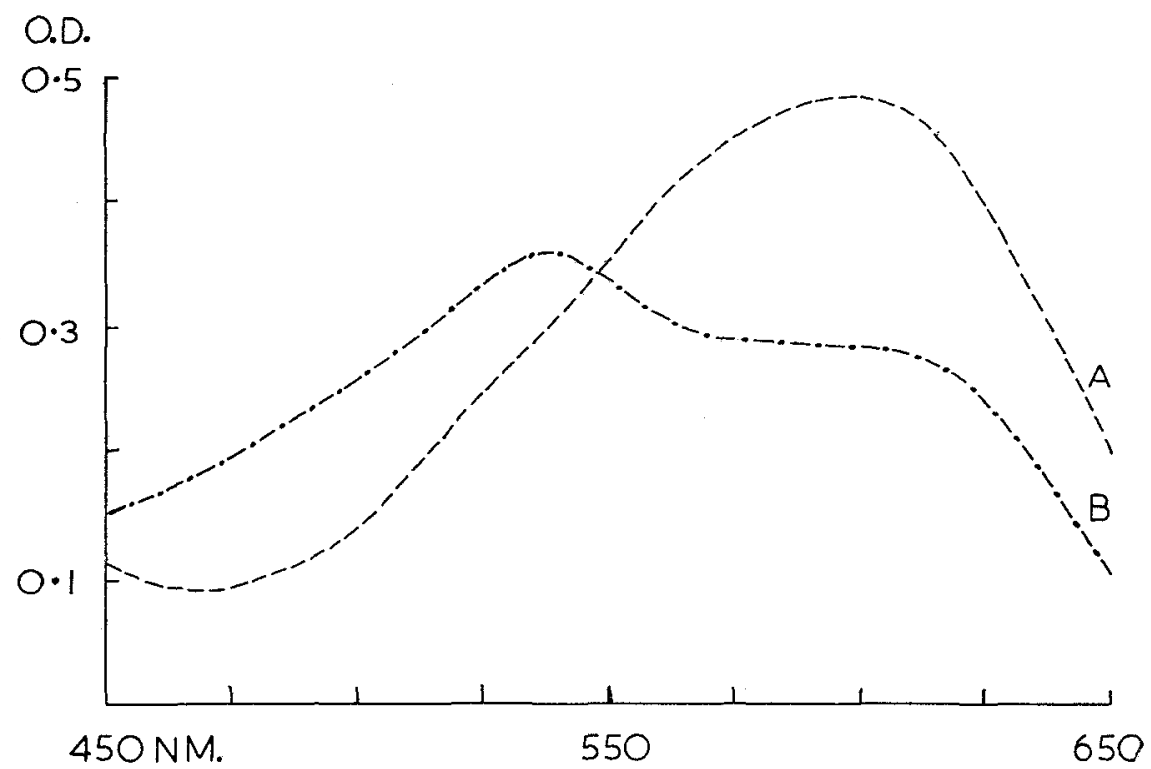

Fig. 3. Spectral curves from 450 to $650 \mathrm{~nm}$ of A: neat dye and B: dye + magnesium, $2 \mathrm{mg}$ per $100 \mathrm{ml}$ (1 cm Unicam SP 500$)$.

to the concentration of magnesium. Serum is added to Mann dye in alkaline ethanolic solution. The decrease in optical density at $600 \mathrm{~nm}$ is compared with that of a standard magnesium solution similarly treated. To compensate for any turbidity produced by the serum, the test is read against a serum blank without dye. 

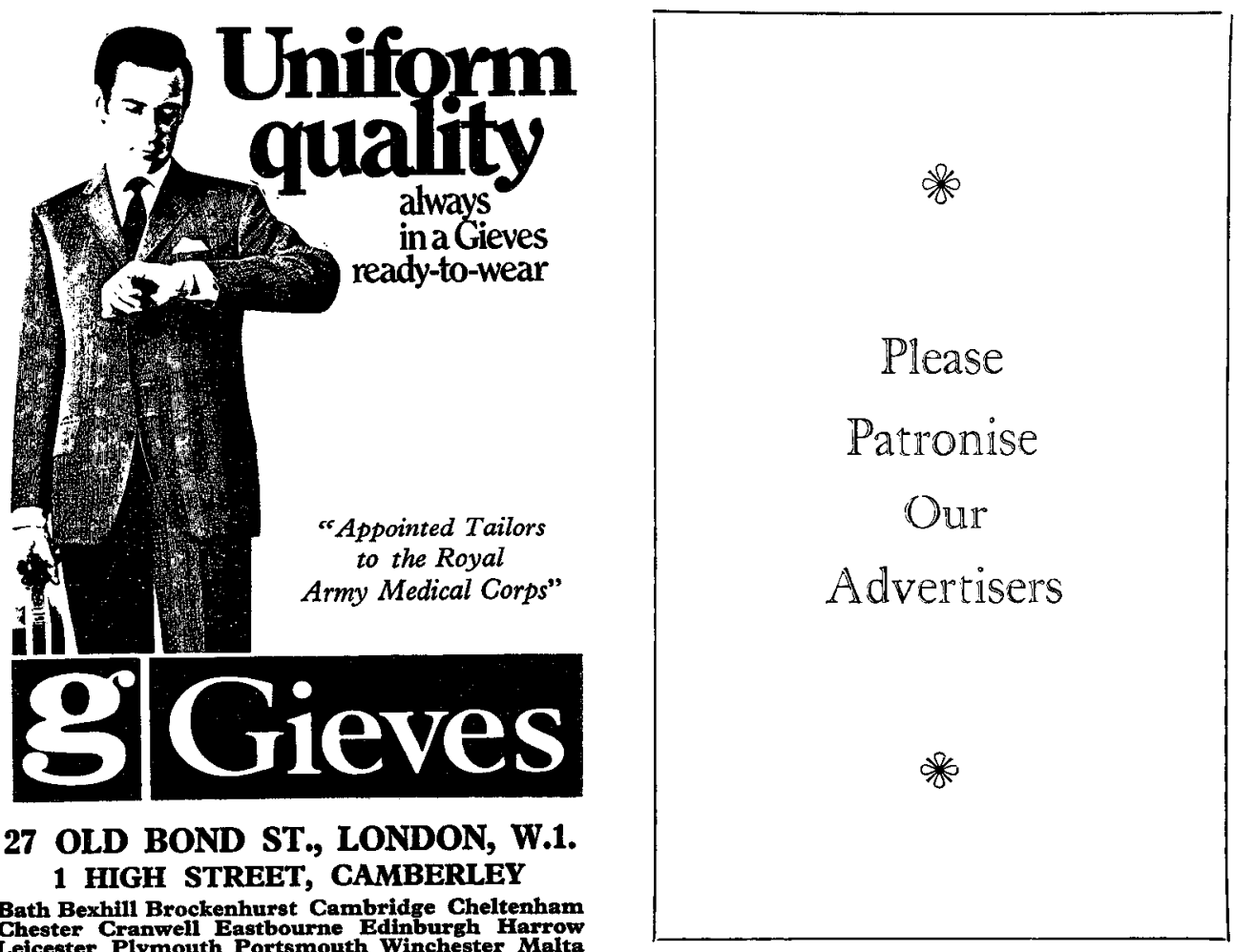

27 OLD BOND ST., LONDON, W.1. 1 HIGH STREET, CAMBERLEY

Bath Bexhill Brockenhurst Cambridge Cheltenham

Chester Cranwell Eastbourne Edinburgh Harrow

Leicester Plymouth Poxtsmouth Winchester Malta

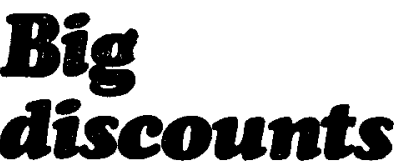

on your

new car

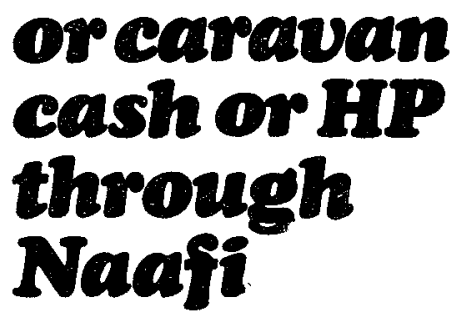

Naafi doesn't actually sell you the car or caravan. Naafi's part of the deal is to see that it costs you as little as possible. This is how:

DISCOUNTS FROM $7 \frac{1}{2} \%$ TO $13 \%$ OFF THE BASIC PAICE of most popular British cars and $7 \frac{1}{2} \%$ to $10 \%$ OFF touring caravans bought. through a Naafi introduction, from a dealer in the UK for UK or overseas use.

SPECIAL EXPORT DISCOUNT OF 15\% OFF many Austin, Morris, Triumph and Rover cars bought through a Naafi introduction, if you are being posted abroad from the UK or from one overseas country to another.

FIRST CLASS HP TERMS and low HP charges without strings such as annual subscriptions.

DELIVERY TO SUIT YOUR CONVENIENCE - car to the airport When you arrive in the UK, to your home town or new station; your caravan to your home town in UK or to an overseas port. THESE ARE THE WORLD WIDE ADVANTAGES OF USING NAAFI HP

Entitlement to fult dealer services retained $\square$ Free personal insurance -Insurance cover against three quarters of your liability to purchase tax and import duty on a car - subject to simple conditions - if prematurely repatriated from overseas $\square$ Naafi provides deposit saving facilities to build up a deposit for a future purchase.

Naafi will also finance the purchase of used cars in UK and Germany. See your Naafi Manager for full details or in case of difficulty complete this coupon without obligation.

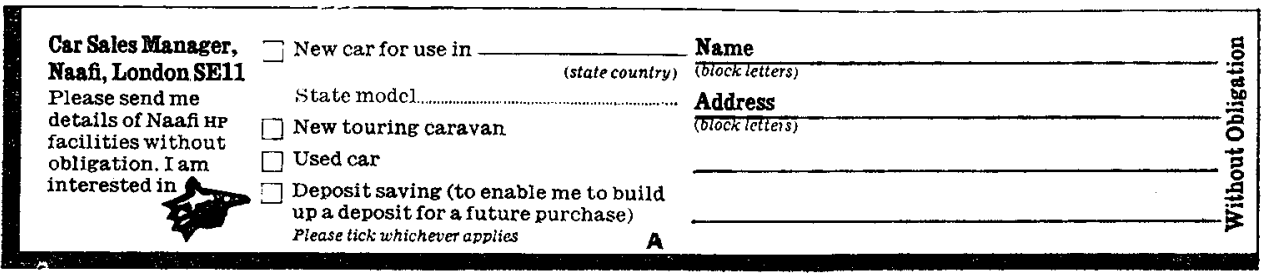




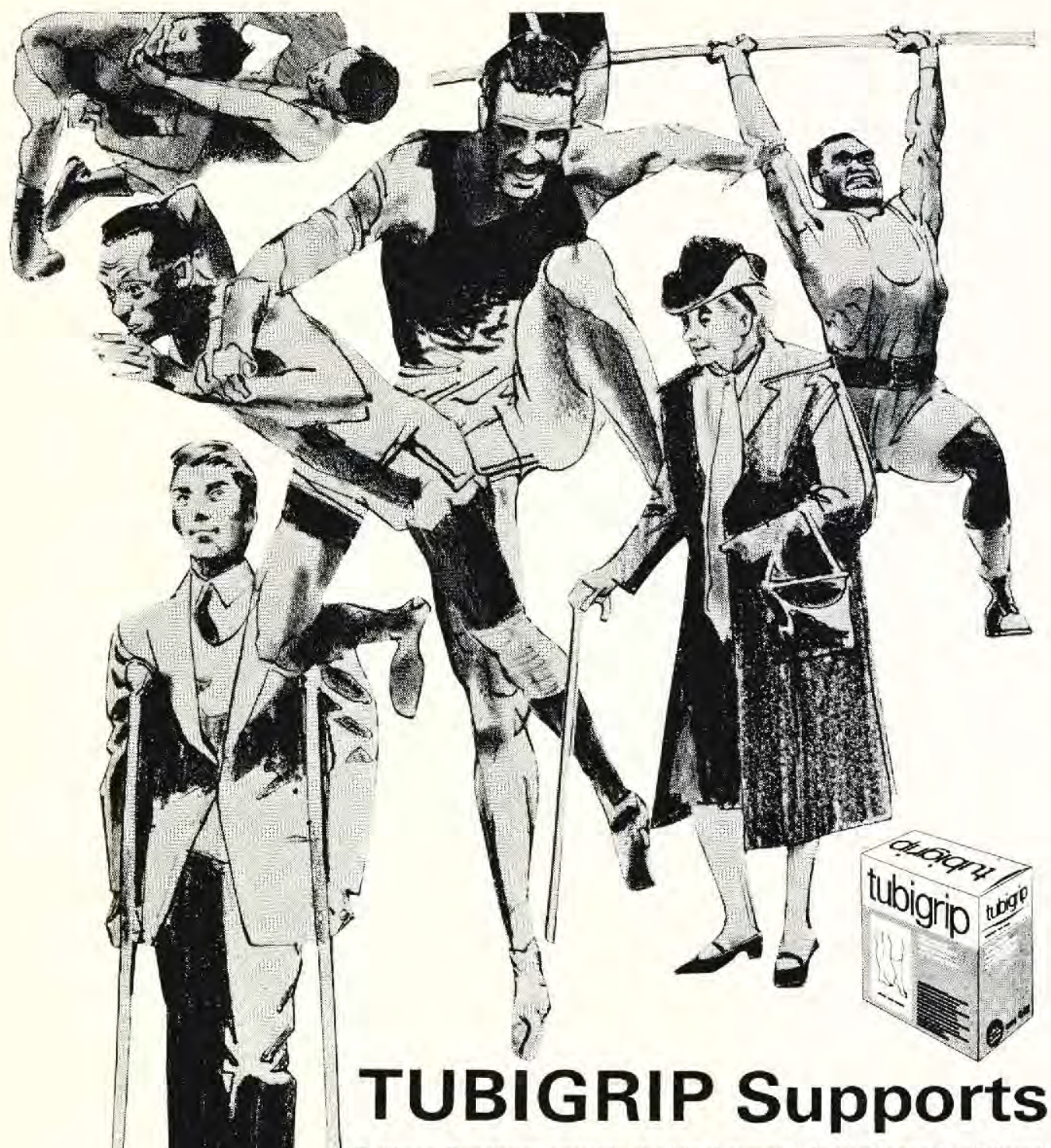

Tubigrip Bandages provide the ideal support for weakened or injured muscles and joints, and for a wide variety of varicose, circulatory and other conditions. They give that constant, evenly distributed support which brings relief and confidence to the patient, without the bulk and inconvenience of conventional bandaging.

Self-retaining Tubigrip Bandages are easy to apply, economical in use, and maintain their elasticity through several washings. There are 9 sizes available, in $1 \mathrm{~m}$ or $10 \mathrm{~m}$ packs, which cover every application, from infant to adult limbs and trunks. In England \& Wales, and Northern Ireland three of these sizes are prescribable in $\frac{1}{2} \mathrm{~m}$ or $1 \mathrm{~m}$ lengths, the half metre lengths are also prescribable in Scotland.

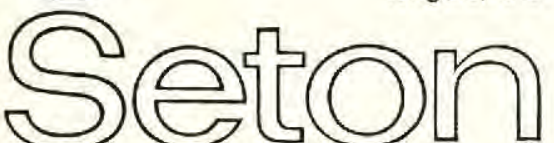

Products Limited

\section{A Member of the Seton Group}

Tubiton House, Medlock St., Oldham, Lancashire, England. Telephone: 061-652 2222 (5 lines) Telegrams: "Tubiton" Oldham. Manufacturers and world distributors of specialised surgical dressings and appliances. 


\section{Reagents required}

(a) Stock dye reagent. Dissolve $25 \mathrm{mg}$ dye in $200 \mathrm{ml}$ of ethanol and make up to $250 \mathrm{ml}$ with water. Stable indefinitely.

(b) Sodium borate, $0.08 \mathrm{M}$. Dissolve $3.05 \mathrm{~g} \mathrm{Na}_{2} \mathrm{~B}_{4} \mathrm{O}_{7} \cdot 10 \mathrm{H}_{2} \mathrm{O}$ in hot water, cool and dilute to $100 \mathrm{ml}$.

(c) Serum blank reagent. Mix 44,8 and $48 \mathrm{ml}$ rêspectively of water, $0.08 \mathrm{M}$. borate and ethanol. Stable indefinitely.

(d) Dye reagent. Mix 50,10 and $40 \mathrm{ml}$ respectively of water, $0.08 \mathrm{M}$ borate and ethanol. This is stable indefinitely and for use, mix 4 volumes of this with 1 volume of dye. The mixed dye reagent must be used the same day.

(e) Standard magnesium. Dissolve $0 \cdot 1233 \mathrm{~g} \mathrm{MSO}_{4} \cdot 7 \mathrm{H}_{2} \mathrm{O}$ in water and make up to $100 \mathrm{ml}$. This is a $10 \mathrm{mEq} /$ litre solution. For use dilute 1 in 5 for a $2 \mathrm{mEq} /$ litre working standard.

Method

For each sample put up blank and test. Into semimicro cuvettes pipette $1 \mathrm{ml}$ of dye reagent for the test and $1 \mathrm{ml}$ of serum blank reagent for the blank. To each add $0.005 \mathrm{ml}$ of serum, cap with parafilm and mix. For a neat dye tube, take $1 \mathrm{ml}$ of dye reagent and add to it $0.005 \mathrm{ml}$ of water. The standard tube consists of $1 \mathrm{ml}$ of dye reagent and $0.005 \mathrm{ml}$ of working standard. Read the test against the serum blank, the neat dye and standard against water at $600 \mathrm{~nm}$.

Calculate the $\mathrm{mEq} / \mathrm{litre}$ as under:

$$
\frac{\text { O.D. neat dye tube - O.D. test }}{\text { O.D. neat dye tube - O.D. standard }} \times 2
$$

Notes

1. Turbidity. In most cases, particularly if fasting sera are insisted upon, the serum blank may be omitted.

2. Beer's law. The method obeys Beer's law up to at least $4 \mathrm{mEq} /$ litre of magnesium. The readings are stable from 5 minutes to at least 6 hours.

3. Commercial kits. The method of Rice and Lapara (1964) is an improvement upon the method of Bohuon (1962) who used the difference in absorption between free and magnesium bound dye at 500 $\mathrm{nm}$. A kit based on the Bohuon method, the reagents in which can also be used for the Rice and Lapara method, is available and includes a magnesium standard and an alcoholic solution of Mann dye, from Pye Unicam Limited, Cambridge.

4. Normal range. This is quoted as $1.5-2.0 \mathrm{mEq} / \mathrm{litre}$ for serum Bajpai et al. (1966) using this technique found a mean of $1.51 \mathrm{mEq} /$ litre (range $1.2-1.8$ ) for infants in the first week of life and a mean of $1.82 \mathrm{mEq} /$ litre (range $1.4-2 \cdot 0$ ) for older infants.

\section{Bilirubin. A. Spectrophotometric method}

Serum is diluted 1 in 51 with a phosphate buffer pH 7.4 The optical density is measured at $460 \mathrm{~nm}$ which is the peak absorbance of unconjugated bilirubin in serum. Correction for oxyhaemoglobin, which also absorbs at $460 \mathrm{~nm}$ is made by deducting the optical density at $549 \mathrm{~nm}$ from that at 460 . Haemoglobin at $\mathrm{pH} 7.4$ exhibits identical absorbance at these wavelengths whereas bilirubin has a minimal absorbance at $549 \mathrm{~nm}$ (Fig. 4). The corrected reading at $460 \mathrm{~nm}$ is related to a similarly treated bilirubin in serum standard.

\section{Reagents required}

(a) Phosphate buffer, $\mathrm{pH} 7 \cdot 4$. Dissolve $4.05 \mathrm{~g} \mathrm{Na}_{2} \mathrm{HPO}_{4}$ and $1.74 \mathrm{~g} \mathrm{KH}_{2} \mathrm{PO}_{4}$ in water and make up to 1 litre. Preserve with a drop of chloroform.

(b) Bilirubin in serum standard. Versatol Pediatric (Warner) is used as a standard (see notes) reconstituted in dim light according to the package instructions.

\section{Method}

Into 2 small tubes pipette $1 \mathrm{ml}$ of buffer with a volumetric pipette. Keeping the samples out of direct daylight add to one tube $0.02 \mathrm{ml}$ of test serum and $0.02 \mathrm{ml}$ of standard bilirubin to the other. Cap with parafilm and invert to mix. Transfer immediately to $2 \mathrm{~cm}$ micro cuvettes and read against buffer at 460 and $549 \mathrm{~nm}$ in a spectrophotometer. Calculate the concentration of bilirubin in the test as follows:

Concentration of bilirubin (mg per $100 \mathrm{ml}$ ) = Test O.D. $460 \mathrm{~nm}$-Test O.D. $549 \mathrm{~nm}$ X factor

$$
\text { Factor }=\frac{\text { Stated bilirubin value of standard }}{\text { Std. O.D. } 460 \mathrm{~nm}-\text { Std. O.D. } 549 \mathrm{~nm}}
$$

Under the conditions in this laboratory the standard factor averages $30 \cdot 5$. This should be checked weekly with a fresh reconstituted Versatol.

Notes

1. Wavelength selection. The isobestic points of oxyhaemoglobin comparable with the bilirubin maximum must be checked for each individual instrument. These points inevitably fall on the steep 


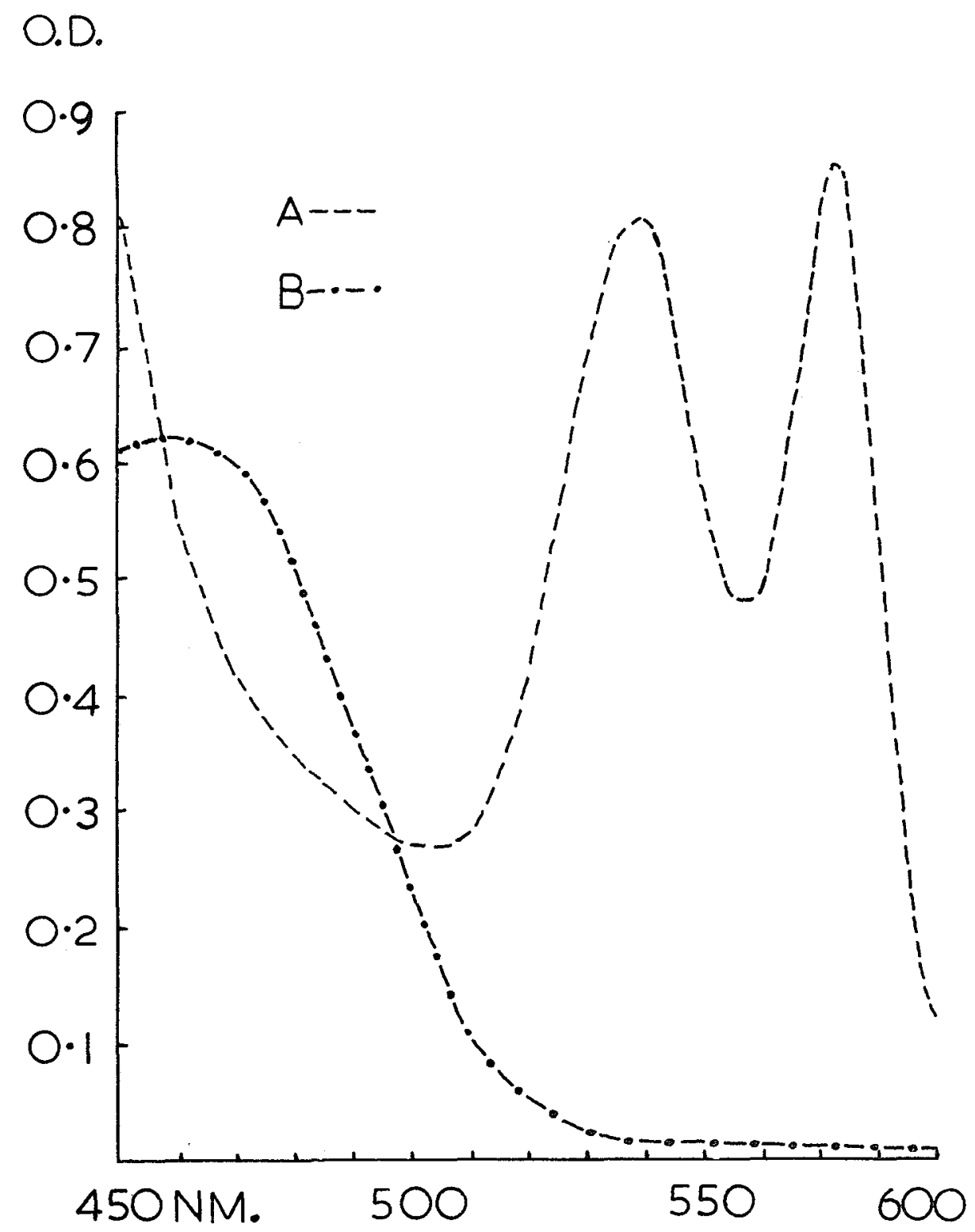

Fig. 4. Spectral curves of bilirubin and oxyhaemoglobin at $\mathrm{pH} 7.4$ from 450 to $600 \mathrm{~nm}$. A: oxyhaemoglobin and B: bilirubin, $20 \mathrm{mg}$ per $100 \mathrm{ml}$ ( $2 \mathrm{~cm}$ Unicam SP 500).

curves of the alpha and beta absorption bands of oxyhaemoglobin so that a small error in wavelength selection at the correction point will result in inaccuracy. The correction point for oxyhaemoglobin is best taken from the least steep curve of the alpha band. Plot the absorption curve of a diluted bilirubin in serum standard from 455 to $465 \mathrm{~nm}$ and determine the exact wavelength of the peak. The optical density of a suitably diluted oxyhaemoglobin solution in buffer is then measured at this wavelength. The isobestic point on the alpha band of the oxyhaemoglobin solution is found by plotting the optical density curve from 545 to $555 \mathrm{~nm}$. The isobestic wavelengths thus found are then used routinely for the particular instrument concerned.

2. Standard bilirubin. According to the written specifications of Versatol, it conforms to the recommendations of the American Academy of Pediatrics and others (1962). Such a grade exhibits a mole- 
cular absorbance of 59,800 as azobilirubin at $540 \mathrm{~nm}$ in the presence of serum. Several batches of Versatol Pediatric and Versatol A Abnormal were checked by the recommended diazo method (Henry 1966). The mean molecular absorbance found was $59,600 \pm 300$ at $540 \mathrm{~nm}$ with 4 different batch numbers. This was considered sufficient evidence to support the adoption of Versatol Pediatric as a primary bilirubin standard.

3. Conjugated bilirubin. The practice of estimating bilirubin by spectrophotometric techniques lis only accurate with increased bilirubin concentrations and in the absence of significant amounts of other serum chromogens and conjugated bilirubin (Watson and Rogers 1961). The latter component exhibits a different wavelength maximum from serum unconjugated bilirubin (Fog and Bakken 1967). These conditions are only present in the first few days of life when conjugated bilirubin remains less than $2 \mathrm{mg}$ per cent in normal infants (Stevens 1965). The method can be used for slightly older infants when the reasons for jaundice are essentially haemolytic and the concentrations of conjugated bilirubin are there-1 fore insignificant.

4. Effect of Haemolysis. Since most neonatal samples for bilirubin estimation are probably collected by heel prick, the effect of haemolysis is an important factor in the selection of a particular method. Provided that the correction wavelength for haemoglobin has been accurately determined, the spectrophotometer methud gives satisfactory results even in the presence of gross haemolysis. To illustrate this, oxyhaemoglobin was added to Versatol Pediatric serum to give various final concentrations and bilirubin estimations were performed by the spectrophotometric method above and by the method of Lathe and Ruthven (Varley 1967). The results are shown in Table III.

Table III

Effects of haemolysis on Bilirubin methods

\begin{tabular}{|c|c|c|c|c|c|c|c|}
\hline Method & \multicolumn{7}{|c|}{ Concentrations } \\
\hline $\begin{array}{l}\text { Bilirubin prêsent mg per } 100 \mathrm{ml} \\
\text { Haemoglobin present } \mathrm{mg} \text { per } 100 \mathrm{ml} \\
\text { Bilirubin found: }\end{array}$ & $\begin{array}{l}16 \cdot 35 \\
23 \cdot 30\end{array}$ & $\begin{array}{l}17 \cdot 80 \\
12 \cdot 70\end{array}$ & $\begin{array}{l}18 \cdot 8 \\
5 \cdot 40\end{array}$ & $\begin{array}{c}10 \cdot 0 \\
5 \cdot 00\end{array}$ & $\begin{array}{l}10 \cdot 0 \\
2 \cdot 50\end{array}$ & $\begin{array}{l}10 \cdot 0 \\
1.25\end{array}$ & $\begin{array}{l}10 \cdot 0 \\
\mathrm{Nil}\end{array}$ \\
\hline $\begin{array}{l}\text { Lathe and Ruthven } \\
\text { Spectrophotometric }\end{array}$ & $\begin{array}{l}13 \cdot 7 \\
16 \cdot 30\end{array}$ & $\begin{array}{l}16 \cdot 0 \\
17 \cdot 7\end{array}$ & $\begin{array}{l}17 \cdot 6 \\
18 \cdot 7\end{array}$ & $\begin{array}{l}8 \cdot 9 \\
9 \cdot 95\end{array}$ & $\begin{array}{r}9 \cdot 7 \\
10 \cdot 1\end{array}$ & $\begin{array}{r}9 \cdot 7 \\
10 \cdot 1\end{array}$ & $\begin{array}{l}9 \cdot 90 \\
10 \cdot 0\end{array}$ \\
\hline
\end{tabular}

The claim that the method of Lathe \& Ruthven is accurate in the presence of up to $1 \mathrm{~g}$ of oxyhaemoglobin per $100 \mathrm{ml}$ (Watson 1960) is unjustified.

\section{Bilirubin. B. Diazo method (Martinek 1966)}

Where the estimation of conjugated bilirubin is necessary the method of Martinek, which uses similar reagents to that of Lathe and Ruthven, is satisfactory although it is affected by haemolysis to approximately the same degree as the latter method. The sensitivity of the Martinek version is some 100 per cent greater than that of most diazo/ methanol methods and is particularly suitable for samples showing only slight increases. Bilirubin in serum is coupled with diazotised sulphanilic acid. Reaction between unconjugated bilirubin and the diazo reagent is promoted by the addition of methanol.

Reagents required

(a) Bilirubin standard: Versatol Pediatric (Warner) is used.

(b) Diazo A: Dissolve 1g sulphanilic acid in water containing $1.5 \mathrm{ml}$ of conc. $\mathrm{HC} 1$ by heating. Make up to $100 \mathrm{ml}$ with water.

(c) Diazo B: $0.5 \mathrm{~g} \mathrm{NaNO}_{2}$ per $100 \mathrm{ml}$ in water. at $4^{\circ} \mathrm{C}$.

(d) Diazo mixture: $0.5 \mathrm{ml}$ of B mixed with $10 \mathrm{ml}$ of A. Reactive for at least six hours when kept

(e) Methanol: Aqueous 90 per cent v/v.

\section{Method}

For direct bilirubin: Into 2 small tubes pipette $0.4 \mathrm{ml}$ of diazo A for the blank and $0.4 \mathrm{ml}$ of mixed diazo for the test. Add $0.02 \mathrm{ml}$ of unhaemolysed serum to both, mix well and start a timer. At 1 minute transfer the tube contents to $1 \mathrm{~cm}$ micro cuvettes and read the test against the blank at $560 \mathrm{~nm}$ in a spectrophotometer.

For total bilirubin: Put up a second pair of tubes as above and allow to stand for 5 minutes. Then add $0.4 \mathrm{ml}$ of methanol, mix well and read at $560 \mathrm{~nm}$ between 5 and 15 minutes after adding the methanol. Treat a Versatol Pediatric standard in exactly the same way. 
Notes

1. Beer's law: This is obeyed up to $20 \mathrm{mg}$ per $100 \mathrm{ml}$ and $10 \mathrm{mg}$ per $100 \mathrm{ml}$ direct reading concentrations of bilirubin. For values greater than this, the sample should be diluted 1:1 with water at the outset.

2. Colour stability: The azo pigment is stable from 5 to 15 minutes after addition of methanol. After this time fading occurs to give an approximate 3 per cent negative error at 30 minutes.

\section{Acknowledgements}

I am indebted to Colonel T. G. A. L. Warrington for his co-operation and advice, to Lieutenant-Colonel L. W. Padgett of the Louise Margaret Maternity Hospital for providing cord blood samples and to Colonel M. Munro and Mr. F. Pinion of the Army Blood Supply Depot for the blood donor samples and antenatal sera.

\section{Equipment}

1. Beckman/Spinco ultramicro analytical system. Beckman International Division, Fullerton, California. United Kingdom distributors, Hawkesley \& Sons Ltd. Lancing, Sussex.

2. Mikrolitersystem ' Eppendorf R'. United Kingdom distributors, V.A. Howe Ltd., 46 Pembridge Road, London, W.11.

3. Pye Unicam Ltd. York Street, Cambridge CB1 2PX, England.

4. British Joint Services Catalogue of Medical Equipment, H.M.S.O., London.

5. Emil " gold line".

6. Technicon Instrument Co. Ltd., Basingstoke, Hants.

7. Hawkesley \& Sons Ltd., Lancing, Sussex.

\section{REFERENCES}

American Academy of Pediatrics (1962. Clin. Chem. 8, 405.

Babson, A. L. Greeley, S. J., Coleman, C. M. and Phillips, G. E. (1966) Clin. Chem. $12,482$.

Bajpai, P. C., Sugden, D., Ramos, A. and Stern, L. (1966). Arch. Dis. Childh. $41,424$.

Bartholomew, R. J. and Delaney, Aileen M. (1966). Proc. Austral. Assoc. Clin. Biochem. $1,214$.

BoHuOn, C. (1962). Clin. chem. Acta. 7, 811.

Clayton, Barbara E. and Jenkins, P. (1966). J. clin. Path. 19, 293.

Dryer, R. L., TAMmes, A. R. and Routh, J. I. (1957). J. biol. Chem. 225, 177.

FOG, J. and BAKKEN, A. F. (1967). Scand. J. clin. Lab. Invest. $20,88$.

Goldfarb, A. R., Saidel, L. J. and Mosovich, E. (1951). J. biol. Chem. 193, 397.

Harding, J. R. and KeYser, J. W. (1968). Proc. Ass. clin. Biochem. 5, 51.

Henry, R. J., Sobel, C. and Berkman, S. (1957). Anal. Chem. 29, 1491.

Henry, R. J.'(1966). Clinical Chemistry, Principles and Techniques. Harper \& Row, London.

Keyser, J. W. (1965). Clin. chim. Acta. 11, 479.

MartineK, R. J. (1966). Clin. chim. Acta. 13, 161.

Nankiville, Diane D., and Watson, D. (1964). Clin. chim. Acta. 9, 359.

Nisselbaum, J. A., Schlamouitz, M. and Bodansky, O. (1961). Ann. N. Y. Acad. Sci. $94,970$.

Northam, N. E. and Widdowson, G. M. (1967). Tech. Bull. No. 11. Assoc. Clin. Biochem.

Radin, N. and Gramza, A. L. (1964). Clin. Chem. 10, 704.

Rice, E. W. and LAPara, C. Z. (1964). Clin. chim. Acta. 10, 360.

Stevens, J. (1965).J. Med. Lab. Technol. 22, 47.

Tombs, M. P., Souter, F. and MacLagen, N. F. (1959). J. Biochem. 73, 167.

Trinder, P. (1969). Ann. Clin. Biochem. 6, 24.

VARLeY, H. (1967). Practical Clinical Biochemistry, 4th ed. Heinemann, London.

Watson, D. and Rogers, Janice A. (1961). J. Clin. Path. 14, 271.

Willtamson, T. (1972). J. Med. Lab. Technol. (in print).

Wolf, Marion, Dinwoodie, Allison, and Morgan, H. G. (1969). Clin. chim. Acta. 24, 131. 